\title{
Baitul Maal wat Tamwil (BMT) Berbasis Kearifan Lokal Gorontalo
}

\author{
Sofhian \\ IAIN Sultan Amai Gorontalo \\ fiantomare@iaingorontalo.ac.id
}

\begin{abstract}
This paper is inspired by the practice of helping the people of Gorontalo called it "Huyula". The huyula are aimed to enhence solidarity among fellow community to mutually share the burden when facing problems, including economic issues. The author focuses on the incorporation of the huyulapractice to theBaitul Maal wa Tamwil (BMT) system. This article aims to provide motivation for practitioners of financial institutions particularly the islamic financial institutions, in this case the Baitul Maal wa Tamwil (BMT) in order to increase productivity and cost savings. Because the practice of Baitul Maal wa Tamwil (BMT) with Huyula cultural practices have a common goal which is helping.The focus of this paper is to provide an overview of Gorontalonese symboliccultural indigenous locus: "Culture is basedshariah and the shariah is based on the Qur'an". This study finds out that practice of the huyulaamong the Gorontalonese is genuinely compatible with the implementation of Baitul Maal wa Tamwil (BMT).
\end{abstract}

\begin{abstract}
Abstrak
Fokus tulisan ini adalah memberikan gambaran tentang simbolistik budaya yakni: "Adat bersendikan sara dan sara bersendikan kitabullah" yang ada di Gorontalo. Penggambaran praktek Huyula secara umum pada masyarakat Gorontalo, serta bagaimana implementasi Baitul Maal wa Tamwil (BMT) terhadap keberadaan budaya Huyula bisa diterapkan dengan baik dan benar pada masyarakat Gorontalo yang sangat menjunjung tinggi karakter tersebut. Artikel ini bertujuan untuk memberi motifasi bagi praktisi-praktisi lembaga keuangan khusunya lembaga keuangan syariah, dalam hal ini Baitul Maal wa Tamwil (BMT) guna meningkatkan produktifitas dana simpanan dan pembiayaan. Karena praktek Baitul Maal wa Tamwil (BMT) dengan praktek budaya Huyula memiliki kesamaan tujuan yakni tolong menolong.
\end{abstract}

Keywords : Penguatan, BMT, Basis, Nilai-nilai, Huyula 


\section{A. Pendahuluan}

Perkembangan lembaga keuangan syariah di Indonesia dari sisi inplementasi diawali dengan beroprasinya perbankan syariah pertama yakni Bank Muamalat Indonesia namun hingga saat ini jangkauan terhadap usaha-usaha mikro kecil menengah yang berada di lingkup masyarakat bawah masinh sangat minim, sehingga dibutuhkan peran serta lembaga lain untuk menjadi perpanjangan tangan dari perbankan syariah yang ada sekarang ini, Baitul Maal wat Tamwil (BMT) merupakan sulusi yang sangat efektif untuk menjadi perpanjangan tangan dari lembaga keuangan bank tersebut.

Dekade ini masyarakat yang berada pada lapisan bawah masih merasa sulit untuk mengakses lembaga perbankan termasuk dalam hal ini perbankan syariah, hal tersebut disebabkan karena adanya ketentuan yang di persyaratkan oleh lembaga perbankan dalam mengakses pembiayaan, dengan kata lain lembaga mikro kecil tersebut harus bankebel jika ingin melakukan pembiayaan terhadap perbankan syariah, dan hal tersebut yang masih sulit untuk dipenuhi oleh masyarakat yang memiliki usaha skala mikro dan kecil. Ini menandakan bahwa harus ada lembaga perpanjangan tangan dari perbankan untuk memfasilitasi masyarakat dengan lembaga perbankan syariah, sehingga cita-cita luhur pendirian perbankan syariah dapat terwujud yakni menjangkau masyarakat menengah kebawah dalam akses permodalannya, lembaga tersebut adalah Baitul Maal wat Tamwil (BMT).

Baitul Maal wat Tamwil (BMT) merupakan bagian dari bank syariah atau semacam LSM yang beroperasi seperti bank koperasi dengan pengecualian ukurannya yang kecil dan tidak mempunyai akses ke pasar uang. Baitul Maal wat Tamwil terdiri dari dua istilah yaitu baitul maal dan baitut tamwil. Baitul maal adalah lembaga keuangan umat Islam yang mengelola dana umat islam yang bersifat sosial dan sumber dana baitul mal berasal dari zakat, infaq, sodaqoh, hibah dan lain-lain sedangkan baitul tamwil adalah lembaga keuangan yang mengelola dana umat yang sifatnya komersial yang sesuai dengan syariat Islam. ${ }^{1}$ Baitul Maal wat Tamwil (BMT) berfungsi menghimpun dan menyalurkan dana kepada masyarakat sebagaimana bank atau lembaga keuangan yang lain. Baitul Maal wat Tamwil (BMT) berdiri dengan

\footnotetext{
Makhalul Ilmi, Teori dan Praktek Lembaga Mikro Keuangan Syariah Yogyakarta: UII Press. 2002, h. 65
} 
gagasan fleksibilitas dalam menjangkau masyarakat kalangan bawah yaitu lembaga ekonomi rakyat kecil karena kebanyakan dari mereka adalah pedagang kecil yang tidak bias memanfaatkan fasilitas kredit dari bank umum untuk mengembangkan usaha, hal ini disebabkan prosedur bank umum yang sulit serta kelemahan yang dimiliki oleh pedagang kecil dan pengusaha kecil dalam hal manajemen, pemasaran dan jaminan yang merupakan faktor- faktor penting bagi penilaian bank.

Pada dasarnya prinsip operasi Baitul Maal wat Tamwil terdiri dari; $^{2}$ 1. Sistem Jual Beli; Sistem ini merupakan suatu tata cara jual beli yang dalam pelaksanaanya BMT mengangkat nasabah sebagai agen yang diberi kuasa melakukan pembelian barang atas nama BMT, kemudian bertindak sebagai penjual dan menjual barang yang telah dibelinya tersebut bengan ditambah mark-up. 2. Sistem non-profit; Sistem yang sering disebut sebagai pembiayaan kebijakan ini merupakan pembiayaan yang bersifat sosial dan non komersial, nasabah cukup mengembalikan pokoknya saja. 3. Akad Bersyarikat; Akad bersyarikat adalah kerjasama antara dua pihak atau lebih dan masing-masing pihak mengikutsertakan modal (dalam berbagai bentuk) dengan perjanjian pembagian keuntungan/kerugian yang disepakati. 4. Produk Pembiayaan; Penyediaan uang dan tagihan berdasarkan persetujuan atau kesepakatan pinjam-meminjam diantara BMT dengan pihak lain yang mewajibkan pihak meminjam untuk melunasi utangnya beserta bagi hasil setelah jangka waktu tertentu.

Pada awal tahun 2015 di seluruh Indonesia telah berdiri lebih dari 3.362 Koperasi Jasa Keuangan Syariah termasuk BMT yang tersebar di penjuru negeri ini. Dengan demikian, secara ekonomi lembaga Baitul Maal wa Tamwil (BMT) akan sangat membantu pertumbuhan ekonomi masyarakat. Sebagai contoh, apabila 3.362 Baitul Maal wa Tamwil (BMT) melayani, minimal 1000 orang nasabah, maka sebanyak 3.362.000 penduduk Indonesia dapat dijangkau atau dilayani. Dengan kata lain, dari sisi kuantitas lembaga Baitul Maal wa Tamwil (BMT) adalah banyak. Lembaga ini telah menjadi keuangan rakyat, karena keberadaannya yang dekat dengan rakyat. Sebab lembaga ini, tumbuh dan berkembang dari rakyat bawah (grass root). Akan tetapi, jika dilihat dari sisi kualitasnya, maka masih banyak Baitul Maal wa Tamwil (BMT)

\footnotetext{
${ }^{2}$ Sudarsono, Heri. Bank dan Lembaga Keuangan Syariah. Yogyakarta: Ekonosia, 2005, h.101-102
} 
yang memiliki kinerja ( keuangan, sumber daya manusia, maupun aspek kelembagaan lainnya) yang kurang baik. Jika keadaan ini dibiarkan, maka akan menjadi ancaman berat bagi lembaga tersebut, termasuk di Gorontalo.

Baitul Maal wat Tamwil (BMT) di Gorontalo bisa dikatakan masih mengalami perlambatan dalam perkembangannya sehingga memerlukan pendampingan serius dari pemerhati lembaga keuangan non bank untuk memajukannya secara berkelanjutan termasuk peran serta lembaga keuangan bank syariah untuk melakukan pembinaan dari sisi manajerialnya, hal tersebut disebabkan karena masih kurang pahamnya masyarakat tentang perbedaan operasional antara BMT dengan koperasi secara umum, masih kurangnya sumber daya manusia yang ada dalam mengelola BMT, kurangnya sosialisasi dinas terkait dalam menggalakkan Baitul Maal wat Tamwil (BMT) di provinsi Gorontalo.

Tabel 1.

BMT-BMT di Provinsi Gorontalo sejak tahun 2006

\begin{tabular}{|c|c|c|c|}
\hline No & Nama BMT & Tahun Berdiri & Tempat \\
\hline 1 & BMT Al Hidayah & 2005 & Kab Bone Bolango \\
\hline 2 & BMT AMAI & 2007 & Kota Gorontalo \\
\hline 3 & BMT Tinelo Sejahtera & 2010 & Kab. Gorontalo \\
\hline 4 & BMT Puncak & 2013 & Kab. Gorontalo \\
\hline 5 & BMT Manggabai & 2014 & Kab. Gorontalo \\
\hline 6 & BMT Helumo & 2016 & Kab. Gorontalo \\
\hline
\end{tabular}

Sumber: Dinas Koperasi, UMKM, Perindustrian dan Perdagangan Kab/Kota Gorontalo

Secara kelembagaan BMT didukung oleh Pusat Inkubasi Bisnis Usaha Kecil (PINBUK), PINBUK pada dasarnya menadapatkan pengakuan dari Bank Indonesia sebagai lembaga pengembagan swadaya masyarakat, PINBUK sebagai lembaga primer karena mengemban misi yang sangat luas, karena pada dasarnya BMT dapat didirikan dan dibentuk oleh kelompok swadaya masuarakat (KSM) dan koperasi. Sebelum menjalankan usahanya seharusnya kelompok swadaya 
masyarakat mendapatkan izin dari dinas terkait dalam hal ini Dinas Koperasi setempat jika berbadan hokum koperasi namun jika berbadan hukum Lembaga Keuangan Mikro (LKM) maka izin harus di peroleh dari kantor regional Otoritas Jasa Keuangan (OJK) tempat berdirinya BMT tersebut. Tugas BMT membantu usaha-usaha mikro dan kecil sehingga dapat dikatakan keberadaan BMT pada dasarnya representative dari masyarakat di mana BMT itu berada, dengan jalan inilah BMT dapat mengakomodir kepentingan masyarakat banyak. Pembentukan BMT di Gorontalo masih tetap ada, hal tersebut dapat dilihat pada data perkembangan diatas, dan hamper setiap tahunnnya selalu ada BMTBMT baru yang terbentuk, namun dari sisi market sharenya tidak dapat di pungkiri bahwa masih membutuhakan penguatan metode baru dalam peningkatannya, ada hal yang menarik di Gorontalo ketika dikaitkan dengan pengelolaan BMT, yakni mengembangkan BMT dengan melalui pendekatan kearifan lokal/ local wisdom yakni mengelola BMT dengan pendekatan tradisi "Huyula", yakni mengembangkan BMT dengan menjadikan adat tolong menolong sebagai fondasi utamanya, hal tersebut penting karena masyarakat Gorontalo masih sangat kental dengan simbolistik budaya yang dipadukan dengan kekuatan syariat, oleh karena itu penting kiranya membangun Baitul Maal wat Tamwil (BMT) dengan pendekatan kearifan lokal dengan simbolistik Adati hula hula Sareati, Sareati hula hula to Kitabullah yang artinya, Adat Bersendikan Syara, Syara Bersendikan Kitabullah.

Berdasarkan kondisi di atas, maka penting kiranya kearifan lokal/ local wisdom menjadi penyemangat dalam mengelola dan mengembangkan BMT di Gorontalo, oleh karena itu penulis tertarik untuk melanjutkan tulisan ini lebih jauh lagi dengan mengkaji penguatan Baitul Maal wa Tamwil (BMT) berbasis nilai-nilai kearifan lokal yang kuat (Huyula) guna kemajuan lembaga dan perekonomian masyarakat Gorontalo. Tulisan ini merupakan sebuah usaha untuk mengembangkan model tentang penguatan budaya Huyula pada lembaga Baitul Maal wa Tamwil (BMT) agar tetap bertahan di tengah-tengah masyarakat yang pengaruh arus globalisasi dan informasi yang semakin kuat. Formula dimaksud adalah mengkondisikan budaya Huyula sesuai dengan konteks pengelolaan Baitul Maal wa Tamwil (BMT), sehingga masalah pokok dalam tulisan ini yakni transformasi nilai-nilai budaya Huyula pada Baitul Maal wa Tamwil (BMT) dapat terejawantahkan pada pembangunan karakter bangsa khusunya pada Daerah Gorontalo 


\section{B. Transformasi Nilai Kearifan Lokal Gorontalo}

Menurut kuntowijoyo Transformasi adalah konsep ilmiyah atau alat analisis untuk memahami dunia. ${ }^{3}$ Karena dengan memahami perubahan setidaknya dua kondisi/keadaan yang dapat diketahui yakni keadaan pra perubahan dan keadaan pasca perubahan. Transformasi merupakan usaha yang dilakukan untuk melestarikan budaya local agar tetap bertambah dan dapat dinikmati oleh generasi berikutnya agar mereka memiliki karakter yang tangguh sesuai dengan karakter yang tangguh sesuai dengan karakter yang disiratkan oleh ideology pancasila.

Transformasi merupakan perpindahan atau pergeseran suatu hal kearah yang lain atau beru tanpa merubah struktur yang terkandung didalammnya, meskipun dalam bentuknya yang baru telah mengalami perubahan. Kerangka transformasi budaya manusia. Transformasi secara tipikal didahului oleh bermacam-macam indicator social. Transformasi budaya semacam ini merupakan langkah-langkah esensial dalam perkembangan peradaban. Semua peradaban berjalan melalui kemiripan siklus proses-proses kejadian, pertumbuhan, keutuhan, dan integritas. Beberapa ilustrasi pemahaman transformasi tersebut maka dapatlah disimpulkan bahwa transformasi adalah perpindahan dari suatu tempat ketempat yang lain, dan menyebabkan perubahan pada suatu obyek yang telah di hinggapi oleh sesuatu tersebut. Jadi transformasi dapat menyebabkan perubahan pada suatu obyek tertentu. Perubahan tersebut terjadi pula pada masyarakat yang mampu mentransformasi nilai-nilai budaya local khususnya budaya huyula yang berada pada masyarakat Gorontalo sebagai dasar keberhasilan pembangunan karakter bangsa.

Menurut Hoffman dalam Hakam yang mengemukakan teori moral socialization atau teori moral sosialisasi menguraikan bahwa perkembangan moral mengutamakan perpindahan norma dan nilai-nilai dari masyarakat kepada anak agar anak tersebut kelak menjadi anggota masyarakat yang memahami nilai dan norma yang terdapat dalam budaya masyarakat, teori ini menekankan pada nilai dan norma yang tadinya terdapat dalam budaya masyarakat ditransformasikan atau disampaikan kepada masyarakat lain agar masyarakat secara umum memiliki atau memahami nilai-nilai budaya dan dapat dijadikan dasar dalam kehidupan

3 Kuntowijoyo, Budaya dan Masyarakat (Edisi Paripurna), (Yogyakarta, Tiara Wacana), 2006, h.56 
bermasyarakat, berbangsa, dan bernegara. ${ }^{4}$

Di Gorontalo terdapat simbolistik yang sarat akan makna keagamaan yakni Adati hula hula Sareati, Sareati hula hula to Kitabullah yang artinya, Adat Bersendikan Syara, Syara Bersendikan Kitabullah. Relevansi Nilai-nilai Adat Bersendikan Syara, Syara Bersendikan Kitabullah, Memuliakan Ilmu untuk Mencerdaskan Bangsa, Menggali Nilai-nilai Adat Bersendikan Syara, Syara Bersendikan Kitabullah yang relevan dengan tugas pendidik dan tenaga kependidikan tersebut juga menjadi konsen IAIN Sultan Amai Gorontalo terutama pada kajian ekonomi khususnya kajian ekonomi syariah, salah satunya adalah komitmen dan usaha memuliakan ilmu untuk mencerdaskan bangsa. Memuliakan ilmu untuk mencerdaskan bangsa menjadi relevan dalam meninggikan derajat bagi seseorang, suatu kaum ataupun bangsa yang memiliki peradaban keilmuan. Hal ini dipertegas dalam Hadits yang diriwayatkan Muslim dari Abu Hurairah artinya "Barang siapa menempuh suatu jalan untuk menuntut ilmu, maka dengan ilmunya itu Allah mempermudah jalan ke Surga". Untuk mengaktualisasikan cita-cita menuju surga Allah Swt, dalam aktivitasnya seorang pendidik dan tenaga kependidikan mestinya bekerja penuh keikhlasan, dan menjadikan nilainilai kerjanya itu sebagai ibadah dalam kapasitasnya mencerdaskan bangsa. Hal ini relevan dengan isi Al-qur'an surat Al-Jumuah ayat

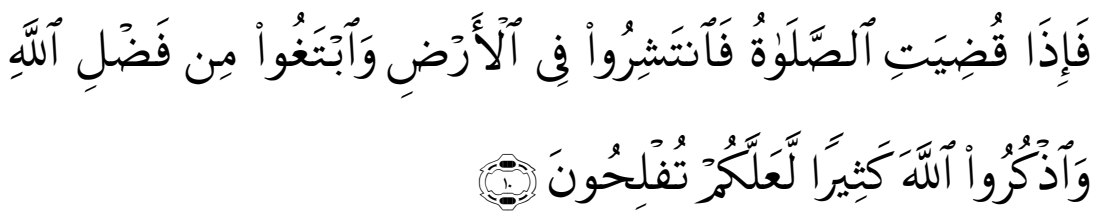

Terjemahnya : "Apabila telah ditunaikan Shalat, maka betebaranlah kamu dimuka bumi mencari karunia Allah, dan ingatkanlah Allah sebanyak banyaknya agar kamu beruntung".

Maksud dari ayat tersebut menurut tafsir jalalayn Apabila telah ditunaikan salat, maka bertebaranlah kalian di muka bumi) perintah ini menunjukkan pengertian ibahah atau boleh (dan carilah) carilah rezeki (karunia Allah, dan ingatlah Allah) dengan ingatan (sebanyak-banyaknya supaya kalian beruntung) yakni memperoleh keberuntungan. Pada hari

\footnotetext{
${ }^{4}$ Hakam, A.K. Bunga Rampai Pendidikan Nilai, (Bandung, Universitas Pendidikan Indonesia), 2007, h. 131 - 132
} 
Jumat, Nabi saw. berkhutbah akan tetapi tiba-tiba datanglah rombongan kafilah membawa barang-barang dagangan, lalu dipukullah genderang menyambut kedatangannya sebagaimana biasanya. Maka orang-orang pun berhamburan keluar dari mesjid untuk menemui rombongan itu, kecuali hanya dua belas orang saja yang masih tetap bersama Nabi saw. lalu turunlah ayat ini.

Pesan religious ini memberikan isyarat bahwa setiap pendidik yang memahami kerja merupakan ibadah kepada Allah sebagai manifestasi kehidupan manusia untuk menunjukkan ketaatan pada Allah SWT yang menciptakan alam dan segenap isinya. Sehingga usaha memuliakan ilmu mencerdaskan bangsa pada hakekatnya seorang pendidik, sembari beribah sesuai dengan kapasitasnya. Dalam manajemen Adat Bersendikan Syara, Syara Bersendikan Kitabullah sebagai enkulturasi nilai-nilai budaya lokal yang di mulai dari inventarisasi budaya, memaksimal peran akademisi untuk mensosialisasikan dan mengimplementasikan nilai Adat Bersendikan Syara, Syara Bersendikan Kitabullah sebagai kekayaan budaya lokal yang mesti diwarisi ke generasi berikutnya.

\section{Budaya Huyula Masyarakat Gorontalo}

Tradisi Gotong Royong bagi masyarakat Gorontalo dikenal dengan istilah Huyula yang menjadi ciri khas kepribadian masyarakat Gorontalo yang telah dibina secara turun temurun. Dalam buku perjuangan Rakyat Daerah Gorontalo, menentang kolonialisme dan mempertahankan Negara proklamasi, praktek Huyula bagi masyarakat Gorontalo merupakan suatu sistem tolong menolong antara anggotaanggota masyarakat, untuk memenuhi kebutuhan dan kepentingan bersama yang didasarkan pada solidaritas social melalui ikatan keluarga, tentangga, dan kerabat.

Mochtar dalam Mohamad mengemukakan Huyula adalah pernyataan kebersamaan dalam membangun, atau kebiasaan memusyawarahkan setiap kebijak yang akan diambil yang berhubungan dengan kepentingan dan hajat hidup orang banyak, berdasarkan pendapat tersebut Huyula merupakan bentuk musyawarah dalam hal merumuskan kebijak yang akan menjadi dasar dalam pelaksanaan pembangunan demi kepentingan bersama, hal yang sama dikemukakan oleh Daulima, dia mengatakan bahwa Huyula adalah melakukan suatu pekerjaan bersama oleh sekelompok orang atau anggota masyarakat dalam arti saling 
membantu dan timbale balik. ${ }^{5}$

Huyula bagi masyarakat Gorontalo, penerapannya dapat dilihat dalam beberapa jenis, yaitu: ${ }^{6}$

1. Ambu, merupakan kegiatan tolong menolong untuk kepentingan bersama atau lebih dikenal dengan istilah kerja bakti, misalnya pembuatan jembatan dan sebagainya, selain itu ambu merupakan salah satu cara yang digunakan oleh masyarakat untuk menyelesaikan permasalahan di masyarakat seperti perkelahian antar warga

2. Hileiya, adalah merupakan kegiatan tolong menolong secara spontan yang dianggap kewajiban sebagai anggota masyarakat, misalnya pertolongan yang diberikan pada keluarga yang mengalami kedukaan dan musibah lainnya, termasuk memberikan bantuan keuangan dalam rangka meringankan beban keluarga yang mengalami musibah tersebut.

3. Ti'ayo, adalah kegiatan tolong menolong antar sekelompok orang untuk mengerjakan pekerjaan seseorang, contohnya megerjakan pekerjaan pertanian, membangun rumah, membangun bantayo (tenda) untuk pesta perkawinan.

\section{Implementasi Praktek Baitul Maal wa Tamwil (BMT) pada Tradisi Huyula}

Budaya Huyula merupakan budaya kerjasama atau tolong menolong, selain itu Huyula merupakan bentuk kesadaran masyarakat untuk bergotong royong atau bekerjasama demi kepentingan umum, hal tersebut sejalan dengan pembangunan karakter bangsa yang berbasis budaya local yang dilakukan melalui pendekatan non formal atau informal. Huyula adalah pernyataan kebersamaan dalam membangun masyarakat dengan jiwa tolong menolong dan bahkan lebih luas lagi Huyula merupakan tataran semangat kebersamaan masyarakat untuk membangun kepentingan umum termasuk membangun ekonomi masyarakat.

Di Indonesia merupakan Negara satu-satunya yang memiliki lembaga keuangan mikro syariah yang di sebut Baitul Maal Wa Tamwil (BMT), temasuk dalam hali ini berlaku di Gorontalo, namun hal yang

\footnotetext{
${ }^{5}$ Daulima, F. Aspek-aspek Budaya Masyarakat Gorontalo, Banthayo Pobo 'ide Limboto, (Penerbit Fitrah, 2004), h. 82

${ }^{6}$ Ibid, 83
} 
menarik untuk di kaji lebih jauh adalah adanya praktek budaya yang dilakukan oleh masyarakat Gorontalo yang sangat kental sampai sekarang pembelakuannya yangni budaya Huyula, budaya/ tradisi ini sangat relevan jika dipadukan dengan praktek-praktek yang ada pada Baitul Maal Wa Tamwil (BMT). Sebagai Lembaga Keuangan Mikro Syariah, BMT mempunyai dua sisi kelembagaan yang berbeda, tidak hanya berorientasi pada pengelolaan yang profit tetapi juga mempunyai peran sosial sehingga BMT pada satu sisi menjadikan dirinya dikelola secara professional mengikuti prinsip bisnis, disisi lain tetap membawa misi sosial pada masyarakat (misi huyula), keberadaan BMT ditengahtengah masyarakat sangatlah dibutuhkan untuk mengangkat derajat para pengusaha kecil/mikro yang tidak terjangkau oleh lembaga perbankan dalam layanan permodalan.

BMT merupakan singkatan dari Baitul Maal wa Tamwil atau dapat ditulis dengan Baitul Maal wa Baitul Tamwil. Secara harfiah Baitul Maal berarti rumah dana dan baitul tamwil berarti rumah usaha. Dari pengertian tersebut memiliki makna yang berbeda dan dampak yang berbeda pula. Baitul Maal merupakan lembaga sosial yang berdampak pada tidak adanya profit atau keuntungan duniawi atau material didalamnya, sedangkan baitul tamwil merupakan lembaga bisnis yang pengelolaannya harus berjalan dengan prinsip bisnis yakni efektif dan efesien. Dari uraian tersebut dapat diartikan secara menyeluruh bahwa Baitul Maal wa Tamwil (BMT) merupakan organisasi bisnis yang juga berperan sebagai control social (huyula). Sebagai lembaga sosial, Baitul Maal memiliki kesamaan fungsi dan perannya dengan Lembaga Amil Zakat ( LAZ ) atau Badan Amil Zakat milik pemerintah, oleh karenanya Baitul Maal ini harus didorong untuk mampu berperan secara profesional menjadi LAZ yang mapan. Fungsi tersebut meliputi pengumpulan zakat, infak, sedekah, wakaf dan dana-dana sosial lainnya serta upaya penyalurannya kepada golongan yang paling berhak menurut ketentuaan asnabiah. Sebagaimana dalam QS. At Taubah 60 ; Sesungguhnya zakatzakat itu, hanyalah untuk orang-orang fakir, orang-orang miskin, pengurus-pengurus zakat, para mu'allaf yang dibujuk hatinya, untuk (memerdekakan) budak, orang-orang yang berhutang, untuk jalan Allah dan untuk mereka yuang sedang dalam perjalanan, sebagai suatu ketetapan yang diwajibkan Allah, dan Allah Maha mengetahui lagi Maha Bijaksana. 
Baitul Maal wa Tamwil (BMT) merupakan lembaga bisnis yang memfokuskan usahanya pada sektor keuangan, yakni simpan-pinjam dengan pola syari'ah. Pengelolaan ini hampir mirip dengan usaha perbankan yaitu menghimpaun dana dari anggota masyarakat (kegiatan Funding) dan menyalurkannya kepada sektor ekonomi yang halal dan menguntungkan (kegiatan Financing).

Dari perspektif hukum di Indonesia, sampai saat ini BMT menggunakan badan hukum yang paling memungkinkan adalah dalam bentuk Koperasi baik serba usaha (KSU) atau simpan-pinjam Syariah (KSPS). Dari wacana para praktisi BMT dan keuangan Syariah sangat mungkin dibentuk perundangan-undangan tersendiri bagi BMT, mengingat operasional BMT tidak sama persis dengan koperasi, begitu pula dengan Undang-undang Nomor 1 Tahun 2013 tentang Lembaga Keuangan Mikro (LKM) masih bersifat dual operasional sistem sehingga tetap perlu di dorong untuk pembentukan undang-undang yang spesifik mengakomodir kerja-kerja lembaga keungan micro yang syariah (LKMS) seperti halnya undang-undang perbankan syariah yang telah ada. ${ }^{7}$

Untuk mengoptimalkan operasional Baitul Maal wa Tamwil (BMT) dibutuhkan tenaga SDM yang bekerja sesuai dengan konsep dasar yang dimiliki oleh BMT. Bagi karyawannya bekerja di Baitul Maal wa Tamwil (BMT) tidak hanya akan mendapatkan keuntungan secara duniawi tetapi juga sebagai ibadah dan dakwah dalam melaksanakan syariat ekonomi Islam. Terlebih Baitul Maal wa Tamwil (BMT) adalah lembaga bisnis dan sosial yang banyak membantu masyarakat sehingga disini tidak hanya dibutuhkan pekerja yang profesional tetapi juga bekerja secara ikhlas, memiliki kejujuran, rasa keadilan ,moralitas dan keagamaan yang baik, sehingga hasil dari kerja tersebut memberikan manfaat bagi orang banyak, karena sebaik-baiknya manusia adalah yang memberi manfaat disekelilingnya.

Menurut Bapak Cokro Beberapa karakter yang dimiliki oleh Baitul Maal wa Tamwil (BMT) menjadikannya sebagai lembaga keuangan mikro yang ideal untuk pemberdayaan usaha mikro sekaligus membantu perluasan lapangan kerja bagi masyarakat ekonomi kecil dan menengah. Karakter-karakter tersebut antara lain sebagai berikut: ${ }^{8}$

7 Bapak Lahaji (Ketua Komisi Lembaga Ekonomi Umat MUI Prov. Gorontalo), Wawancara di lakukan pada tanggal 16 November 2016

${ }^{8}$ Bapak Cokro (Kepala Dinas Koperasi, UMKM, Perindustrian dan Perdagangan), Wawancara dilakukan pada tanggal 22 November 2015 
1. Baitul Maal wa Tamwil (BMT) dalam menyalurkan dana (Pembiayaan) bersifat luwes tidak mesti bankable, dengan demikian penyaluran dana dapat menyentuh para pengusah mikro yang tidak terlayani akses permodalan oleh perbankan. Keluwesan disini tetap memperhatikan kelayakan dan kesehatan kredit yang diberikan menurut parameter Baitul Maal wa Tamwil (BMT), karena banyak pengusaha mikro yang sebenarnya layak mendapatkan bantuan kredit tetapi tidak bisa terlayani oleh perbankan disebabkan berbenturan dengan aturan-aturan yang mengikat dalam dunia perbankan,misalnya kelayakan jaminan kredit, memiliki ijin usaha dan persyaratan-persyaratan lainnya yang harus dipenuhi. Disinilah peran Baitul Maal wa Tamwil (BMT) agar para pengusaha mikro tersebut tetap mendapatkan akses permodalan, jangan sampai karena tidak mendapatkan kredit di Bank mereka terjebak oleh pinjamanpinjaman yang diberikan para Rentenir dengan biaya bunga yang sangat tinggi. Sehingga Baitul Maal wa Tamwil (BMT) dapat menjadi jembatan penyelamat antara dunia perbankan dan para rentenir yang bunga pinjamannya sangat mencekik para pengusaha mikro.

2. Ciri yang paling melekat pada Baitul Maal wa Tamwil (BMT) adalah pelayanan jemput bola, para dai/marketing BMT terjun langsung kelapangan menjemput calon nasabah baik nasabah penabung maupun nasabah pembiayaan. Kebanyakan BMT-BMT di Indonesia memiliki kantor yang terletak di pasar-pasar induk dengan demikian lebih mudah pemasarannya dalam menjemput bola para pedagang kecil yang berjualan di pasar. Proses jemput bola ini akan berdampak baik bagi Baitul Maal wa Tamwil (BMT), yakni akan cenderung memiliki para nasabah yang sehat dari sisi pembiayaan (kredit), karena dengan menjemput bola tersebut para dai/marketing Baitul Maal wa Tamwil (BMT) dapat melihat langsung kondisi usaha si pedagang, layak atau tidaknya calon nasabah tersebut mendapatkan kredit pembiayaan dari Baitul Maal wa Tamwil (BMT), tentunya juga dilakukan analisis kelayakan kredit yang lebih mendalam berkaitan dengan usaha yang dibiayai.

3. Baitul Maal wa Tamwil (BMT) adalah Lembaga keuangan yang menerapkan Pola Syariah. Berbeda dengan lembaga keuangan atau perbankan dengan sistem konvensional yang berbasis bunga. Pembiayaan atau penyaluran dana oleh BMT kepada nasabah 
menggunakan akad Bagi hasil(mudharabah) dan atau Jual Beli (murabahah), sehingga transaksi ini tidak akan mendhalimi kedua belah pihak baik Baitul Maal wa Tamwil (BMT) maupun nasabah debitur. Akad bagi hasil akan sama-sama memberikan keuntungan kedua belah pihak karena transaksi ini merupakan transaksi mitra atau kerjasama, bagi hasil yang diberikan tidak tetap tetapi berfluktuatif bisa lebih besar atau lebih kecil berdasarkan penghasilan yang diperoleh nasabah. Sedangkan akad jual beli akan memberikan keamanan bagi kedua belah pihak walaupun suku bunga naik atau turun tidak akan mempengaruhi nilai pembiayaan, karena nilai pembiayaan ditentukan berdasarkan harga beli dan harga jual yang telah disepakati. Nasabah juga tidak dibebankan denda dan finalti bunga yang berganda, sehingga nasabah lebih mudah dan tenang dalam membayar kewajibannya.

4. Walaupun Baitul Maal wa Tamwil (BMT) adalah lembaga keuangan syariah yang mengikuti prinsip-prinsip Ekonomi Islam, namun dalam transaksinya tidak hanya melayani khusus umat Islam saja tetapi juga dapat dilakukan kepada siapa pun termasuk dengan orang-orang non muslim. Karena dalam Ekonomi Islam muamalah itu membawa misi Rahmatan lil'Alamin, bahwa membantu dan memberikan atas dasar kasih sayang itu dilakukan kepada seluruh umat manusia bukan hanya umat Islam.

5. Baitul Maal wa Tamwil (BMT) adalah lembaga keuangan non Bank, bidang usahanya tidak hanya pada jasa keuangan tetapi juga dapat mengembangkan bidang usaha lainnya, seperti misalnya Toko Waserda, Agen Travel, Toko Baju Muslim dan usaha-usaha lainnya yang dianggap memberikan keuntungan secara halal.

6. Seperti yang telah dikemukakan diatas Baitul Maal wa Tamwil (BMT) didalamnya mempunyai dua kelembagaan yang berbeda yaitu Bidang Tamwil untuk orientasi profit ekonomi produktif dan bidang Maal untuk orientasi sosial. Dengan memiliki bidang Maal yang sumber dananya berasal dari zakat, infak dan sedekah dapat digunakan BMT untuk menciptakan entrepreneur-entrepreneur baru berasal dari masyarakat yang tidak mampu (tidak memiliki modal dan agunan untuk pinjaman modal). Karena dana maal dapat diproduktifkan kepada mereka sebagai pinjaman modal usaha yang tidak membebankan biaya bunga atau bagi hasil , tanpa harus memiliki agunan untuk usaha yang dibangun. Sehingga ketika mereka telah berhasil mengelola usahanya dan telah memiliki asset 
yang dapat digunakan sebagai jaminan, status orang-orang ini telah terangkat dari orang-orang yang tidak mampu, tidak punya penghasilan menjadi pengusaha mikro yang berkecukupan, minimal mereka mempunyai penghasilan untuk memenuhi kebutuhan hidupnya. Dana Maal ini terus digulirkan dan digulirkan kepada yang lain, maka semakin banyak yang terbantu semakin banyak juga mengurangi jumlah penganguran dan masyarakat miskin.

Dari keenam karakter di atas tidaklah naif dikatakan, bahwa Baitul Maal wa Tamwil (BMT) adalah dapat dikatakan sebagai lembaga pengelola/penyalur keuangan sekaligus dapat berperan sebagai misi social, khususnya di Gorontalo misi sosial tersebut terdapat dalam budaya yang mengakar pada masyarakat Gorontalo yakni budaya Huyula yang sarat akan makna keagamaan yang terkandung di dalamnya, dan juga biasa dikatakan sebagai Pahlawan Ekonomi Rakyat, karena geraknya untuk rakyat khususnya masyarakat ekonomi kecil dan menengah dimana jumlahnya sangat dominan di negeri ini termasuk di, olehnya itu hal yang sangat penting untuk mensingkronkan tradisi masyarakat Gorontalo (Huyula)dengan implementasi penguatan terhadap Baitul Maal wa Tamwil (BMT) di Gorontalo maka perlu ada regulasi khusus (perda) yang di berlakukan oleh pemerintah guna menumbuhkan dan memajukan praktek-praktek BMT yang sarat akan nilai-nilai budaya Gorontalo khususnya budaya Huyula. ${ }^{9}$

Karena karakternya Baitul Maal wa Tamwil (BMT) dapat menjadi lembaga altenatif untuk program pengentasan kemiskinan dan menjadi pilihan sebagai Lembaga Keuangan Mikro Syariah yang Ideal, untuk itu kehadirannya perlu mendapat sambutan dan dukungan dari pihak manapun, Pemerintah, Lembaga-lembaga yang memberikan Permodalan pada keuangan mikro, kalangan Investor, para Ulama, dan masyarakat umumnya, terutama di Gorontalo pengembangan Baitul Maal wa Tamwil (BMT) sangat prospektif karena didukung oleh mayoritas pendudukanya Muslim termasuk adanya nilai-nilai budaya yang masing di junjung tinggi oleh masyarakat Gorontalo yakni budaya Huyula yang merupakan budaya tolong menolong yang seiring dengan misi ukhrowi Baitul Maal wa Tamwil (BMT) yakni misi Ta'awun.

\footnotetext{
${ }^{9}$ Bapak Roni Mohamad (Dekan Fakultas Ekonomi dan Bisnis Islam IAIN Gorontalo), Wawancara dilakukan pada tanggal 25 November 2016.
} 


\section{E. Kesimpulan}

Berdasarkan tulisan yang telah di jelaskan oleh penulis maka kesimpulan yang dapat di ambil adalah sebagai berikut:

1. Simbolistik Adat Bersendikan Syara dan Syara Bersendikan Kitabullah bagi masyarakat Gorontalo merupakan bentuk nyata dari "university cultur responsibility (UCR)". Mestinya, pendidik, tenaga kependidikan dan masyarakat secara umum turut menjadi penggiat dan melakoni pewarisan nilai-nilai ABS-SBK dalam aktivitasnya di lingkungan masyarakat. Mengelaborasi nilai-nilai "ABS-SBK" menjadi seksi untuk dipublikasikan karena pertama, menjadi filosofi hidup masyarakat Gorontalo, komunitas Hulondhalo terkenal di seanteroa Nusantara sebagai entitas yang "distingtif". yakni memiliki karakternya yang khas yakni pelestarian dan pengamalan kaidah Islam yang di pandang sangat kuat baik di masa lampau maupun kontemporer, ketiga pada saat yang sama masyarakat Gorontalo juga cenderung cair, karena komunitasnya yang relative terbuka, eksvolutif.

2. Budaya Huyula merupakan bentuk musyawarah dalam hal merumuskan kebijak yang akan menjadi dasar dalam pelaksanaan pembangunan demi kepentingan bersama, Budaya Huyula terbagi menjadi tiga bagian yakni Ambu, Hileiya, dan Ti'ayo namun ketika dikaitkan dengan praktek yang ada pada Baitul Maal wa Tamwil (BMT) maka praktek tersebut terakomodir oleh budaya Hileiya.

3. Baitul Maal wa Tamwil (BMT) dapat dikatakan sebagai lembaga pengelola/penyalur keuangan sekaligus dapat berperan sebagai misi sosial, khususnya di Gorontalo misi social tersebut terdapat dalam budaya yang mengakar pada masyarakat Gorontalo yakni budaya Huyula yang sarat akan makna keagamaan yang terkandung di dalamnya, dan juga biasa dikatakan sebagai Pahlawan Ekonomi Rakyat,

\section{Daftar Pustaka}

Antonio, M Syafi'i. 2001. Bank Syariah Dari Teori ke Praktek. Jakarta: Gema Insani.

At-tariqi,Abdullah Husain. 2004. Akonomi Islam, Prinsi, Dasar dan Tujuan. Yogyakarta: Magistra Insania Press.

Daulima, 2004, F. Aspek-aspek Budaya Masyarakat Gorontalo, 
Banthayo Pobo'ide Limboto, (Penerbit Fitrah)

Gozali, Ahmad.2005. Serba-Serbi Kredit Syariah. Jakarta: PT. Elex Media Komputindo.

Hakam, A.K. 2007, Bunga Rampai Pendidikan Nilai, (Bandung, Universitas Pendidikan Indonesia),

Harahap, Sofyan S., Wiroso, dan Muhammad Yusuf. 2005 Akuntansi Perbankan Syariah. Jakarta: LPFE Usakti.

Hendry, Arrison. 1999. Perbankan Syariah. Jakarta: Muamalat Institute.

Huda, Nurul, 2013 Lembaga Keuangan Islam, (Jakarta: kencana prenada media group,).

Ilmi, Makhalul. 2002. Teori dan Praktek Lembaga Mikro Keuangan Syariah. Yogyakarta: UII Press.

Irmayanto, Juli. 1998. Bank dan Lembaga Keuangan Lainnya. Jakarta: Media Ekonomi Universitas Trisakti.

Irwanto. 2002. Psikologi Umum. Jakarta: PT. Prenhallindo.

Kirom, Cihwanul, 2015, Strategi Bauran Pemasaran pada Unit Gabungan Terpadu Baitul Maal Wa Tamwil (BMT) Sidogiri, Tesis Program Pasca Sarjana,

Krethner, Robert \& Angelo Kinicki. 2005. Perilaku Organisasi. Jakarta: Salemba Empat.

Kuntowijoyo, 2006, Budaya dan Masyarakat (Edisi Paripurna), (Yogyakarta, Tiara Wacana)

Muhammad, 2008, Bank Syariah; Analisis Kekuatan, Peluang, Kelemahan dan Ancaman, (Yokyakarta, PT Ekonosia)

Muhammad. 2005. Manajemen Pembiayaan Bank Syariah. Yogyakarta: UPP AMP YKPN.

Paeni Mukhlis, 1979, Sejarah Kebangkitan Nasional Daerah Sulawesi Utara,(Jakarta: Balai Pustaka,)

Paeni Mukhlis, 2009, Sejarah Kebudayaan Indonesia: Sistem Sosia..(Jakarta: Rajawali Press,)

Ridwan, Muhammad.2002. Manajemen Baitul Maal Wa Tamwil 
(BMT).

Sudarsono, Heri.2005. Bank dan Lembaga Keuangan Syariah. Yogyakarta: Ekonosia.

Sumitro, Warkum. 1996. Azas-Azas Perbankan Islam dan LembagaLembaga Terkait. Jakarta: PT. Grafindo Persada.

Swastha, Basu. 2001. Azas-Azas Marketing. Yogyakarta: Liberty.

Tangkilisan,Hessel Nogi S. 2003, Manajemen Moderen Sektor Publik, (Yogyakarta: Balaiurang dan $\mathrm{CO}$ ).

Wiroso. 2005. Penghimpunan Dana dan Distribusi Hasil Usaha Syariah. Jakarta: PT.Grasindo

Yusuf,Sri Dewi, 2014 Peran Strategi Baitul Maal Wa Tamwil (BMT) dalam Peningkatan Ekonomi Rakyat, Volume 10 nomor 1. 